Vol. 13 (2004): 268-275.

\title{
Meat and bone meal as nitrogen fertilizer to cereals in Norway
}

\author{
Alhaji Jeng, Trond Knapp Haraldsen, Nils Vagstad, Arne Grønlund \\ Norwegian Centre for Soil and Environmental Research, Frederik A. Dahls vei 20, N-1432 Ås, Norway, \\ e-mail: trond.haraldsen@jordforsk.no
}

Steinar Tveitnes

Department of Plant and Environmental Sciences, Agricultural University of Norway, N-1432 Ås, Norway

\begin{abstract}
Meat and bone meal (MBM) contains appreciable amounts of nitrogen $(\mathrm{N})$, phosphorus and calcium making it interesting as fertilizer to various crops. The effect of Norwegian MBM as N fertilizer has been evaluated in pot and field experiments. The soils used in the pot experiment were peat and a sand/peat mixture, both low in content of plant nutrients. The field experiment was carried out on a silt loam. In the pot experiment increasing amounts of MBM gave significantly increased yields, although there was a partly $\mathrm{N}$ immobilisation shortly after seeding the soil based on peat organic matter. In the field experiment there was no period of $\mathrm{N}$ immobilisation and good $\mathrm{N}$ effect was found also for small amounts of MBM (Total N $50 \mathrm{~kg} \mathrm{ha}^{-1}$ ). At total $\mathrm{N} 100 \mathrm{~kg} \mathrm{ha}^{-1}$ there were no significant differences in grain yield of spring wheat between the treatments with MBM, mineral $\mathrm{N}$ fertilizer, and combination of MBM and mineral $\mathrm{N}$ fertilizer ( $50 \mathrm{~kg} \mathrm{ha}^{-1}$ from each). The results indicate that the relative $\mathrm{N}$ efficiency of MBM compared to mineral fertilizer is $80 \%$ or higher, if MBM is applied to cereals in spring.
\end{abstract}

Key words: fertilizers, meat bone meal, nitrogen use efficiency, organic farming, organic fertilizers, phosphorus

\section{Introduction}

Meat and bone meal (MBM) has been widely used as a valuable protein and mineral source in diets of production animals (Hendriks et al. 2002). Development of animal transmissive spongiform encephalopathies (TSE), like ovine scrapie and bovine spongiform encephalopathy (BSE) has been linked to feeding ruminants with MBM contaminated with transmissive agents (Brewer 1999). Therefore the use of MBM to ruminants was banned in the European Union in 1994, and the use of MBM to all production animals was banned in 2000 in the European Union and most other European countries (Kam- 
Vol. 13 (2004): 268-275.

phues 2002). This situation has forced the meat production industry to look for alternative use of MBM.

The large content of nitrogen $(\mathrm{N})$, phosphorus and calcium in MBM makes it interesting as fertilizer to various crops. The effects of MBM as $\mathrm{N}$ fertilizer to wheat were evaluated by Salomonsson et al. (1994, 1995). They found better utilization of $\mathrm{N}$ from MBM than from pig slurry, and similar $\mathrm{N}$ utilization as urea N. MBM has been found to give sufficient $\mathrm{N}$ supply for good baking performance of organically grown wheat (Fredriksson et al. 1997, 1998). Mixing MBM in soil has been found to increase the potato quality, due to reduced incidence of potato scab (Verticillium dahliae) and decreased populations of parasitic nematodes (Lazarovits et al. 1999, Lazarovits 2001).

Norway produces about 40,000-45,000 metric tons of MBM annually. Based on the fact that BSE has not been recorded in Norway, minimal import of cattle and no import of meat and bone meal to Norway have been executed, the risk for spread TSE agents in Norway has been found to be negligible (EU commission 2000, Fossum et al. 2001, EFSA 2004). Meat and bone meal is therefore allowed to be used as fertilizer in Norway to all crops, except grassland which are used for grazing or mowing (Norwegian Ministry of Agriculture 2002).

Because most of the N in MBM is organically bound and must be transformed to inorganic $\mathrm{N}$ in order to be available for plants, a pot experiment for evaluation of the $\mathrm{N}$ fertilizer value was started in 2001, and followed up by a field experiment in 2002. The practical aim of these experiments was to achieve sufficient scientific basis for fertilizer recommendations for MBM.

\section{Material and methods}

\section{Analysis of meat and bone meal}

Four samples of MBM, representing four different daily productions, were collected from Norsk
Protein's destruction factory at Hamar, and analyzed at the laboratory.

$\mathrm{pH}$ was determined according to NS-EN 12176. Total contents of phosphorus (P), calcium $(\mathrm{Ca})$ magnesium $(\mathrm{Mg})$, potassium $(\mathrm{K})$, lead $(\mathrm{Pb})$, cadmium $(\mathrm{Cd})$, zinc $(\mathrm{Zn})$ and nickel $(\mathrm{Ni})$ were determined after aqua regia dissolution of the material according to the Norwegian Standard 4770 (NS 4770) by simultaneous ICP-AES, using a Perkin Elmer 3000 DV.

Kjeldahl-nitrogen was determined by the Kjeldahl method (Bremner 1960). $\mathrm{NO}_{3}-\mathrm{N}$ and $\mathrm{NH}_{4}-\mathrm{N}$ were determined after extraction with 2 M KCl (Henriksen and Selmer-Olsen 1970, Selmer-Olsen 1971) Total organic carbon was determined by combustion of a crushed sample at $925^{\circ} \mathrm{C}$ using a Perkin Elmer $2400 \mathrm{CHN}$ analyzer, after treatment with $2 \mathrm{M} \mathrm{HCl}$ to remove any inorganic carbon.

Readily available P (P-AL) was determined on ICP after extraction with a solution composed of $0.4 \mathrm{M}$ acetic acid and $0.1 \mathrm{M}$ ammonium lactate, buffered to pH 3.75 (Egnér et al. 1960).

\section{Evaluation of fertilizer effects of MBM}

The effect of MBM as fertilizer was studied in both the greenhouse and in the field in autumn of 2001 and spring of 2002, respectively.

\section{Pot experiment}

The experiment was conducted under greenhouse conditions using constructed growth media [pure peat (Sphagnum) and sand-peat mixture (peat $\left.0.3 \mathrm{~m}^{3} \mathrm{~m}^{-3}\right)$ ]. The soils were limed with $\mathrm{CaCO}_{3}$, equivalent with $12 \mathrm{Mg} \mathrm{ha}^{-1}$ for the peat and 4.5 $\mathrm{Mg} \mathrm{ha}^{-1}$ for the sand/peat mixture in order to increase the $\mathrm{pH}$ to 6.5 . At start of the experiment the $\mathrm{C} / \mathrm{N}$ ratio was 68 in the peat and 20 in the sand/peat mixture. MBM was applied in rates of 0,760 and $2280 \mathrm{~kg} \mathrm{ha}^{-1}$, to give total $\mathrm{N}$ applications of 0,60 and $180 \mathrm{~kg} \mathrm{ha}^{-1}$. The highest rate should represent normal $\mathrm{N}$ fertilization for grain under greenhouse conditions in Norway. MBM was applied alone or in combination with mineral $\mathrm{N}$ in the form of calcium nitrate $\left(\mathrm{Ca}\left(\mathrm{NO}_{3}\right)_{2}\right)$. 


\section{Jeng, A. et al. Meat and bone meal as nitrogen fertilizer}

Table 1. Combinations of meat and bone meal (MBM) and inorganic fertilizer nitrogen $(\mathrm{N})$ used in the pot experiments in autumn 2001.

\begin{tabular}{lrcc}
\hline Treatments & $\begin{array}{c}\mathrm{N} \text { in } \\
\mathrm{MBM}, \\
\mathrm{kg} \mathrm{ha}^{-1}\end{array}$ & $\begin{array}{c}\mathrm{N} \text { in } \\
\text { mineral } \\
\text { fertilizer, } \\
\mathrm{kg} \mathrm{ha}^{-1}\end{array}$ & $\begin{array}{r}\text { Total N } \\
\text { applied, } \\
\mathrm{kg} \mathrm{ha}^{-1}\end{array}$ \\
\hline 0. No fertilizer & 0 & 0 & 0 \\
1. $\mathrm{MBM}_{1}$ & 60 & 0 & 60 \\
2. $\mathrm{MBM}_{2}$ & 180 & 0 & 180 \\
3. $\mathrm{N}_{1}$ & 0 & 90 & 90 \\
4. $\mathrm{MBM}_{1+} \mathrm{N}_{1}$ & 60 & 90 & 150 \\
5. $\mathrm{MBM}_{2+} \mathrm{N}_{1}$ & 180 & 90 & 270 \\
6. $\mathrm{N}_{2}$ & 0 & 180 & 180 \\
7. $\mathrm{MBM}_{1+} \mathrm{N}_{2}$ & 60 & 180 & 240 \\
8. $\mathrm{MBM}_{2+} \mathrm{N}_{2}$ & 180 & 180 & 360 \\
\hline
\end{tabular}

Mineral $\mathrm{N}$ was given at the rates of 0,90 and $180 \mathrm{~kg} \mathrm{ha}^{-1}$. The total $\mathrm{N}$ supply to the different treatments is shown in Table 1. All treatments received a base fertilizer of macro- and micro plant nutrients, based on $\mathrm{K}_{2} \mathrm{SO}_{4}\left(\mathrm{~K} 240 \mathrm{~kg} \mathrm{ha}^{-1}\right.$, $\mathrm{S} 90 \mathrm{~kg} \mathrm{ha}^{-1}$ ) and chlorides of $\mathrm{Mg}, \mathrm{Cu}, \mathrm{Zn}, \mathrm{Mn}$ and $\mathrm{Fe}$, causing nitrogen to be the growth limiting nutrient. Treatments without MBM were given a P supply of $20 \mathrm{~kg}$ or $\mathrm{P} 40 \mathrm{~kg} \mathrm{ha}^{-1}$ as $\mathrm{Ca}\left(\mathrm{H}_{2} \mathrm{PO}_{4}\right)_{2}$. Treatments with MBM received 0 , 20 or $40 \mathrm{~kg} \mathrm{P} \mathrm{ha-1.} \mathrm{Because} \mathrm{the} \mathrm{P}$ supply was sufficient for normal plant growth at each level of $\mathrm{N}$ fertilization, the experiment could not be used to quantify the $\mathrm{P}$ fertilization potential of MBM. There were three replicates for each of the original treatments. Because the differences in $\mathrm{P}$ application gave no yield effects, the treatments with P (20 and $\left.40 \mathrm{~kg} \mathrm{ha}^{-1}\right)$ were combined giving six replicates for the $\mathrm{N}$ treatments.

Thirty seeds of spring barley (Hordeum vulgare, cv. Thule) were sown in the Kick-Brauckman pots in the first week of October. After germination the number of seedlings per pot was thinned to 20 . These reached maturity and were harvested in the last week in January. The day temperature was $20^{\circ} \mathrm{C}$ and the night temperature was $15^{\circ} \mathrm{C}$. In the period $0800-1600$ the light was daylight, while artificial light 10000-15000 Lux was given 1600-0800. An invasion by the Blackberry aphid (Sitobion avenae), six weeks before harvest, was treated with the systemic insecticide Croneton.

\section{Field experiment}

Experiences from the greenhouse experiments were used to develop the experimental plan for the field experiment. The plan was a randomized complete block design with seven treatments and four replicates (Table 2).

The experiment was located to the Agricultural University of Norway (59 39' N, $10^{\circ} 45^{\prime} \mathrm{E}$ ). The soil at the experimental was a poorly drained silt loam (17\% clay) of marine origin, which was slightly acidic ( $\mathrm{pH}$ 6.3). The soil belongs to the

Table 2. Plan for the field experiment.

\begin{tabular}{|c|c|c|c|c|}
\hline \multirow[t]{3}{*}{ Treatments } & \multirow{3}{*}{$\begin{array}{l}\text { Applied } \\
\text { amount } \\
\text { MBM, } \\
\mathrm{kg} \mathrm{ha}^{-1}\end{array}$} & \multicolumn{3}{|c|}{$\begin{array}{l}\text { Applied amount fertilizer, } \\
\qquad \mathrm{kg} \mathrm{ha}^{-1}\end{array}$} \\
\hline & & \multicolumn{2}{|c|}{ Total N } & \multirow[t]{2}{*}{ Total P } \\
\hline & & MBM & Min. N & \\
\hline A. No fertilizer & 0 & 0 & 0 & 0 \\
\hline B. $\mathrm{MBM}_{1}$ & 630 & 50 & 0 & 35 \\
\hline C. $\mathrm{MBM}_{2}$ & 1260 & 100 & 0 & 70 \\
\hline D. $\mathrm{MBM}_{3}$ & 2530 & 200 & 0 & 140 \\
\hline E. Mineral N, no $\mathrm{P}$ & 100 & 0 & 100 & 0 \\
\hline F. No $\mathrm{N}+$ mineral $\mathrm{P}$ & 0 & 0 & 0 & 35 \\
\hline G. $\mathrm{MBM}_{1}+\min . \mathrm{N}$ & 630 & 50 & 50 & 35 \\
\hline
\end{tabular}

$\mathrm{MBM}=$ meat and bone meal 
Vol. 13 (2004): 268-275.

series Eko6 (Kolkind silt loam above silty clay loam), which has been classified as Stagni-Umbric Albeluvisol according to FAO (1998). The contents of readily available (AL-extractable) $\mathrm{P}$ was low (3.5 mg $100 \mathrm{~g}^{-1}$ soil), $\mathrm{K}$ was medium

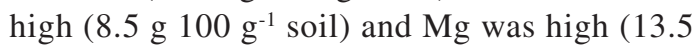
g $100 \mathrm{~g}^{-1}$ soil). This soil normally has relatively large content of non-exchangeable $\mathrm{K}\left(\mathrm{K}-\mathrm{HNO}_{3}\right.$ $>90 \mathrm{mg} 100 \mathrm{~g}^{-1}$ ), which is important for $\mathrm{K}$ sup-

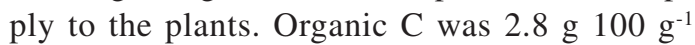

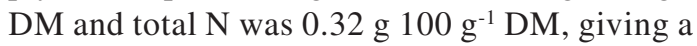
$\mathrm{C} / \mathrm{N}$ ratio of nine.

A base fertilization with magnesium sulphate (Mg $15 \mathrm{~kg} \mathrm{ha}^{-1}$, S $20 \mathrm{~kg} \mathrm{ha}^{-1}$ ) was applied to all plots. MBM was applied to give $\mathrm{N}$ rates of 50 , $100,200 \mathrm{~kg} \mathrm{ha}^{-1}$ after tilling in early April, in the form of a coarse textured $(<2 \mathrm{~mm})$ powder with a dry matter content of $97 \%$. Even application of the small MBM amounts required for some of the plots was complicated because of the powder form. A commercial mineral $\mathrm{N}$ fertilizer (YARA KAS 27) was applied to compare with equal amounts of total $\mathrm{N}$ in MBM.

Spring wheat (Triticum aestivum cv. Avle) was sown in the second week of April 2002 at a seeding rate of $190 \mathrm{~kg} \mathrm{ha}^{-1}$. Herbicide treatment (a mixture containing Storane $400 \mathrm{ml} \mathrm{ha}^{-1}$ and Express $15 \mathrm{~g} \mathrm{ha}^{-1}$ ) was undertaken in May, and the plots were harvested in middle of August.

After harvest grain yields were recorded for both the pot and field experiments. Samples of grain from individual treatments were analyzed. $\mathrm{N}$ uptake was determined and nitrogen use efficiency (NUE), sometimes referred to as nitrogen recovery, calculated using Equation 1 (Lindén 1997).

\section{$\operatorname{NUE}(\%)=100\left(\mathrm{X}_{\mathrm{f}}-\mathrm{X}_{0}\right) / \mathrm{X}_{\mathrm{r}}$,}

$\mathrm{X}_{\mathrm{f}}=\mathrm{N}$ yield $\left(\mathrm{kg} \mathrm{ha}^{-1}\right)$ from fertilized plots

$\mathrm{X}_{0}=\mathrm{N}$ yield $\left(\mathrm{kg} \mathrm{ha}^{-1}\right)$ form unfertilized plots

$\mathrm{X}_{\mathrm{r}}=\mathrm{N}$ application rate $\left(\mathrm{kg} \mathrm{ha}^{-1}\right)$.

For a specific $\mathrm{N}$ application rate, the ratio of NUE for applied MBM to NUE for applied mineral $\mathrm{N}$ was used as an expression of the relative nitrogen use efficiency (RNUE) compared to mineral nitrogen fertilizer.
Table 3. Chemical characteristics of the Norwegian meat and bone meal used in the experiments.

\begin{tabular}{lc}
\hline Parameter, unit & Mean value \\
\hline $\mathrm{pH}$ & 6.5 \\
Dry matter $(\mathrm{DM}), \mathrm{g}(100 \mathrm{~g})^{-1}$ & 97 \\
Loss on ignition, g $(100 \mathrm{~g})^{-1} \mathrm{DM}$ & 66.4 \\
Total organic C, g $(100 \mathrm{~g})^{-1} \mathrm{DM}$ & 29.0 \\
Total N, g $\left(100 \mathrm{~g}^{-1} \mathrm{DM}\right.$ & 7.89 \\
$\mathrm{C} / \mathrm{N}$ ratio & 3.7 \\
$\mathrm{NH}_{4}-\mathrm{N}, \mathrm{mg} \mathrm{kg}{ }^{-1} \mathrm{DM}$ & 273 \\
$\mathrm{NO}_{3}-\mathrm{N}, \mathrm{mg} \mathrm{kg}{ }^{-1} \mathrm{DM}$ & 0.57 \\
Total P, g $\left(100 \mathrm{~g}^{-1} \mathrm{DM}\right.$ & 5.58 \\
$\mathrm{P}-\mathrm{AL}, \mathrm{g}\left(100 \mathrm{~g}^{-1}\right.$ & 2.23 \\
$\mathrm{~N} / \mathrm{P} \mathrm{ratio}$ & 1.4 \\
Total K, g $\left(100 \mathrm{~g}^{-1} \mathrm{DM}\right.$ & 0.36 \\
Total Ca, g $\left(100 \mathrm{~g}^{-1} \mathrm{DM}\right.$ & 11.1 \\
Total Mg, g $\left(100 \mathrm{~g}^{-1} \mathrm{DM}\right.$ & 0.21 \\
\hline
\end{tabular}

\section{Statistical analysis}

Analysis of variance (ANOVA) of the data was carried out according to the experimental design for the plot experiment and the field experiment. For multiple comparisons the Tukey's studentized range test (HSD) was used $(\alpha=0.05)$.

\section{Results}

\section{Nutrient content in meat and bone meal}

Meat and bone meal is weakly acidic ( $\mathrm{pH} 6.5)$, with an organic matter content of about $50 \%$ (calculated from organic C) (Table 3). The Norwegian MBM is a dry powder $(97 \% \mathrm{DM})$, consisting of particles $<2 \mathrm{~mm}$. The content of the plant nutrients $\mathrm{Ca}, \mathrm{N}$ and $\mathrm{P}$ represent approximately

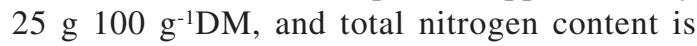

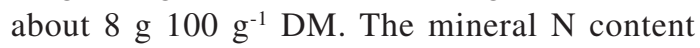
(ammonium $\left(\mathrm{NH}_{4}-\mathrm{N}\right)$ and nitrate $\left.\left(\mathrm{NO}_{3}-\mathrm{N}\right)\right)$ represent approximately $3.5 \%$ of total $\mathrm{N}$. The $\mathrm{C} / \mathrm{N}$ ratio of 3.7, however, indicates a large potential for $\mathrm{N}$ mineralization. 


\section{Jeng, A. et al. Meat and bone meal as nitrogen fertilizer}

Total (aqua regia extractable) P was $5.6 \mathrm{~g} 100$ $\mathrm{g}^{-1} \mathrm{DM}$. Approximately $40 \%$ of this was extractable by the AL-method (Table 3). The concentrations of potassium and magnesium in MBM

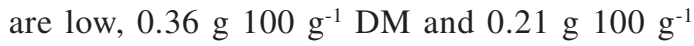
DM, respectively.

\section{Grain yields}

\section{Pot experiments}

Increasing amounts of MBM gave significantly increased yields (Table 4). This effect was significant both without extra $\mathrm{N}$-fertilizer (Treatments 1 and 2), and with increasing amounts of mineral $\mathrm{N}\left(\mathrm{N}_{1}\right.$, Treatments 4 and $5, \mathrm{~N}_{2}$, Treatments 7 and 8). Application of mineral $\mathrm{N}$-fertilizer caused larger yield response for the largest MBM application $\left(\mathrm{MBM}_{2}\right)$ compared to Treatment 2 without added mineral $\mathrm{N}$. The treatments 2, 3 and 4 gave approximately the same grain yields (Table 4). The yield level at Treatments 5 and 6 was not significantly different. The best $\mathrm{N}$-fertilizer response of MBM was found at Treatment 8, which represented the highest levels of MBM and mineral N, and also had the highest yield.

\section{Field experiment}

In the field experiment the treatments without $\mathrm{N}$-fertilizer (Treatments A and F) gave small yields (Table 5). The yield obtained by the smallest amount of MBM $\left(\mathrm{MBM}_{1}, 630 \mathrm{~kg} \mathrm{ha}^{-1}, \mathrm{~N} 50\right.$ $\mathrm{kg} \mathrm{ha}^{-1}$ ) was not significantly different from Treatment $G$, which had received the same amount of MBM and $\mathrm{N} 50 \mathrm{~kg} \mathrm{ha}^{-1}$ in mineral fertilizer. There were no statistical significant yield differences $(\mathrm{P}<0.05)$ between the treatments where N $100 \mathrm{~kg} \mathrm{ha}^{-1}$ was applied (Treatments $\mathrm{C}, \mathrm{E}$ and $\mathrm{G})$. The treatment $\mathrm{D}$ with the double amount of MBM compared to Treatment $\mathrm{C}$ gave marginal and not significant yield increase for the increased MBM application.

\section{Nitrogen uptake and efficiency}

In the pot experiment $\mathrm{N}$ uptake increased with $\mathrm{N}$ application. The $\mathrm{N}$ uptake was greater for mineral $\mathrm{N}$ fertilization treatments than for fertilization treatments with MBM. The control removed only about $\mathrm{N} 3 \mathrm{~kg} \mathrm{ha}^{-1}$, emphasizing the poor $\mathrm{N}$ status of the soils used in the pot experiment. While the application of $\mathrm{N} 180 \mathrm{~kg} \mathrm{ha}^{-1}$ as MBM resulted in yield removal of about $\mathrm{N} 35 \mathrm{~kg} \mathrm{ha}^{-1}$,

Table 4. Grain yields as a function of meat and bone meal (MBM) and nitrogen (N) application rates in the greenhouse (values associated with the same letter are not significantly different $\alpha=0.05$ ).

\begin{tabular}{|c|c|c|c|c|}
\hline \multirow[b]{2}{*}{ Treatments } & \multirow{2}{*}{$\begin{array}{l}\text { Nitrogen rate, } \\
\qquad \mathrm{kg} \mathrm{ha}^{-1}\end{array}$} & \multicolumn{2}{|c|}{$\begin{array}{c}\text { Grain yield, } \\
\text { kg ha }^{-1}\end{array}$} & \multirow{2}{*}{$\begin{array}{l}\text { Mean } \\
\text { yield, } \\
\mathrm{kg} \mathrm{ha}^{-1}\end{array}$} \\
\hline & & mixture & Peat & \\
\hline 0 . No fertilizer & 0 & 246 & 810 & $528 \mathrm{a}$ \\
\hline 1. $\mathrm{MBM}_{1}$ & 60 & 831 & 1416 & $1124 \mathrm{a}$ \\
\hline 2. $\mathrm{MBM}_{2}$ & 180 & 2583 & 3231 & $2907 \mathrm{~b}$ \\
\hline 3. Min. $\mathrm{N}_{1}$ & 90 & 2124 & 3054 & $2589 \mathrm{~b}$ \\
\hline 4. Min. $N_{1}+M_{B} M_{1}$ & 150 & 2596 & 3116 & $2856 \mathrm{~b}$ \\
\hline 5. Min. $\mathrm{N}_{1}+\mathrm{MBM}_{2}$ & 270 & 5310 & 6239 & $5774 \mathrm{c}$ \\
\hline 6. Min. $\mathrm{N}_{2}$ & 180 & 5416 & 4989 & $5203 \mathrm{c}$ \\
\hline 7. Min. $\mathrm{N}_{2}+\mathrm{MBM}_{1}$ & 240 & 6475 & 8031 & $7253 d$ \\
\hline 8. Min. $\mathrm{N}_{2}+\mathrm{MBM}_{2}$ & 360 & 9276 & 10635 & $9955 \mathrm{e}$ \\
\hline
\end{tabular}


Vol. 13 (2004): 268-275.

Table 5. Comparison between meat and bone meal (MBM) and mineral nitrogen (N) fertilizer for $\mathrm{N}$ use efficiency in spring wheat grown in a field experiment (values associated with the same letter are not significantly different $\alpha=$ $0.05)$.

\begin{tabular}{|c|c|c|c|c|c|}
\hline \multirow[t]{2}{*}{ Treatments } & \multicolumn{2}{|c|}{$\begin{array}{l}\text { Application } \\
\mathrm{kg} \mathrm{ha}^{-1}\end{array}$} & \multicolumn{2}{|c|}{$\begin{array}{l}\text { Removal } \\
\mathrm{kg} \mathrm{ha}^{-1}\end{array}$} & \multirow[t]{2}{*}{$\begin{array}{c}\mathrm{N} \text { use } \\
\text { efficiency, \% }\end{array}$} \\
\hline & MBM & Total N & Grain yield & Total $\mathrm{N}$ & \\
\hline A. No fertilizer & 0 & 0 & $1540 \mathrm{a}$ & $31.3 \mathrm{a}$ & \\
\hline B. $\mathrm{MBM}_{1}$ & 630 & 50 & $2670 \mathrm{~b}$ & $52.3 \mathrm{~b}$ & 42 \\
\hline C. $\mathrm{MBM}_{2}$ & 1260 & 100 & $3530 \mathrm{~cd}$ & $70.2 \mathrm{~cd}$ & 39 \\
\hline D. $\mathrm{MBM}_{3}$ & 2530 & 200 & $3970 \mathrm{~d}$ & $81.8 \mathrm{~d}$ & 25 \\
\hline E. Mineral N, no P & 0 & 100 & $3690 \mathrm{~cd}$ & $74.7 \mathrm{~cd}$ & 43 \\
\hline F. No $\mathrm{N}+$ mineral $\mathrm{P}$ & 0 & 0 & $1700 \mathrm{a}$ & $34.2 \mathrm{a}$ & - \\
\hline $\mathrm{G} . \mathrm{MBM}_{1}+\min . \mathrm{N}$ & 630 & 100 & $3180 \mathrm{bc}$ & $65.8 \mathrm{bc}$ & 35 \\
\hline
\end{tabular}

the same levels applied of mineral $\mathrm{N}$ resulted in the removal of twice as much $\left(>\mathrm{N} 70 \mathrm{~kg} \mathrm{ha}^{-1}\right)$ (Table 6).

In the field experiment increased $\mathrm{N}$ uptake with increasing $\mathrm{N}$ fertilization was found both for mineral fertilizer and MBM. Application of $\mathrm{N} 100 \mathrm{~kg} \mathrm{ha}^{-1}$ gave N-uptake between N 66 and $75 \mathrm{~kg} \mathrm{ha}^{-1}$, and there was no significant difference between the $\mathrm{N}$ sources mineral $\mathrm{N}$ fertilizer, $\mathrm{MBM}$, or mixture with equal amount of total $\mathrm{N}$ from mineral $\mathrm{N}$ fertilizer and MBM (Table 5).

The $\mathrm{N}$ use efficiency was lower for MBM treatments than mineral fertilizer treatments in the pot experiment. The relative nitrogen use efficiency (RNUE) was found to be only $47 \%$. In the field experiment NUE for grain grown on MBM-treated soils (Treatment C) were compa- rable to that of grain grown on mineral $\mathrm{N}$ treated soils (Treatment E). Calculated RNUE was as high as $91 \%$ for treatment C. For Treatment $\mathrm{G}\left(\mathrm{N} 100 \mathrm{~kg} \mathrm{~N} \mathrm{ha}^{-1}\right.$, equal amounts of total $\mathrm{N}$ from MBM and mineral N), NUE was somewhat lower than for Treatment C. RNUE for Treatment $\mathrm{G}$ was calculated to be $81 \%$, i.e. lower than for MBM alone as $\mathrm{N}$ supplier.

\section{Discussion}

The differences in $\mathrm{N}$ efficiency of MBM in the pot experiment and field experiment may be related to the properties of the growth medium

Table 6. Comparison between meat and bone meal (MBM) and mineral nitrogen $(\mathrm{N})$ fertilizer for $\mathrm{N}$ use efficiency in barley grown in sand/peat mixture in greenhouse.

\begin{tabular}{lcccc}
\hline Treatments & $\begin{array}{c}\text { N application, } \\
\mathrm{kg} \mathrm{ha}^{-1}\end{array}$ & $\begin{array}{c}\text { Grain yield, } \\
\mathrm{kg} \mathrm{ha}^{-1}\end{array}$ & $\begin{array}{c}\text { N uptake, } \\
\mathrm{kg} \mathrm{ha}^{-1}\end{array}$ & $\begin{array}{c}\mathrm{N} \text { use } \\
\text { efficiency, \% }\end{array}$ \\
\hline 0. No fertilizer & 0 & 246 & $2.9 \mathrm{a}^{*}$ & \\
1. $\mathrm{MBM}_{1}$ & 60 & 831 & $9.2 \mathrm{~b}$ & 11 \\
2. $\mathrm{MBM}_{2}$ & 180 & 2583 & $34.9 \mathrm{~d}$ & 18 \\
3. Min. $\mathrm{N}_{1}$ & 90 & 2124 & $28.6 \mathrm{c}$ & 29 \\
6. Min. $\mathrm{N}_{2}$ & 180 & 5416 & $70.6 \mathrm{e}$ & 38 \\
\hline
\end{tabular}

* values accompanied by the same letters are not significantly different at $\alpha=0.05$ 


\section{Jeng, A. et al. Meat and bone meal as nitrogen fertilizer}

used. In the pot experiment peat and sand/peat mixture were used. These had initially relatively high $\mathrm{C} / \mathrm{N}$ ratio, 68 and 20 respectively. The field experiment was carried out on a silt loam with $\mathrm{C} / \mathrm{N}$-ratio of nine. It is likely that application of smallest amounts of MBM (N $\left.60 \mathrm{~kg} \mathrm{ha}^{-1}\right)$ caused a relatively high proportion of the applied $\mathrm{N}$ to be immobilised in the peat and sand/peat mixture shortly after seeding. When more mineral $\mathrm{N}\left(\mathrm{N} 90\right.$ or $\left.180 \mathrm{~kg} \mathrm{ha}^{-1}\right)$ was applied, this immobilisation of $\mathrm{N}$ had less effect on the $\mathrm{N}$ uptake. In the field experiment there was no evidence of $\mathrm{N}$ immobilisation, and even the smallest amount of MBM showed good $\mathrm{N}$ efficiency. The efficiency of MBM in the field experiment was equal or slightly better than that Salomonsson et al. (1994) found for Biofer, which is an organic fertilizer based on meat and bone meal. Salomonsson et al. (1995) found considerably lower NUE values for Biofer than was found for MBM in the present study. The NUE values for MBM found in our field experiment are normal under field conditions using organic fertilizers.

Although almost all the N in MBM is organic, our field experiment show that the RNUE was higher than $80 \%$. Based on 15 field experiments in organic cropped winter wheat Lundström and Lindén (2001) found that the grain yield increase per $\mathrm{kg} \mathrm{N} \mathrm{ha}{ }^{-1}$ was $10 \mathrm{~kg}_{\text {grain }} \mathrm{ha}^{-1}$ for Biofer compared to $39 \mathrm{~kg}$ grain $\mathrm{ha}^{-1}$ for mineral fertilizer. This indicates a lower N utilization of the MBMbased product than was found in previous Swedish experiments and our field experiment. In experiments with spring wheat and barley, Lundström and Lindén (2001) found very limited yield increase for more than $\mathrm{N} 40 \mathrm{~kg} \mathrm{ha}{ }^{-1}$ in Biofer. This was associated with the large supplies of plant-available soil $\mathrm{N}$, partly present in the soil in spring and partly released by mineralization during the growing season.

The differences in $\mathrm{N}$ efficiency between the Norwegian MBM and the Swedish MBM-based product, Biofer, may also be due to differences in product form and texture. The Norwegian MBM is a dry powder (particle size $<2 \mathrm{~mm}$ ), commonly spread using liming equipment. Biofer is in the form of pellets, commonly spread using ordinary fertilizer spreading equipment. As powdered lime and fertilizers often have a more rapid effect than granulated or pelletted products, it is likely that $\mathrm{N}$ mineralization will start more rapidly after application of powdered MBM compared to MBM pellets.

Based on representative analyses from Norsk Protein, the mean nutrient content $(\mathrm{N}-\mathrm{P}-\mathrm{K})$ of Norwegian MBM (8-5-0) represent lower content of $\mathrm{N}$ relative to $\mathrm{P}$ than the Swedish MBM products (Biofer 10-4-0 and 11-3-0). The narrower N/P ratio (approximately 1.8 ) is an indication that the applied $\mathrm{P}$ will invariably exceed the crop $\mathrm{P}$ requirements if $\mathrm{MBM}$ is applied to meet the $\mathrm{N}$ requirement. Most crop N/P uptake ratios range from 4.5 to 9 (Eghball 1996).

The plant available proportion of $\mathrm{P}$ in MBM has not been documented in scientific papers. In the present investigation the treatments with MBM and no extra $\mathrm{P}$ fertilizer showed adequate growth limited by the $\mathrm{N}$ supply in soils with small amounts of readily available P. Because the $\mathrm{P}$ fertilization effects of MBM have not been thoroughly studied, the $\mathrm{N}$ fertilization value has so far been found to be of greatest interest for the fertilization practice. The potassium content of MBM is negligible. Unless there is large reserves of $\mathrm{K}$ in the soil, $\mathrm{K}$ should be supplied when MBM is used as nitrogen fertilizer. In Norway N 100-140 kg ha-1 is normally used for cereals. If MBM is used in order to meet the $\mathrm{N}$ requirement of the plants, it is recommended to expect $80 \%$ of total $\mathrm{N}$ as the $\mathrm{N}$ fertilizer effect. The implications are that $\mathrm{P}$ supplied through the MBM may exceed $\mathrm{P}$ crop demands in the first year. Knowledge about the $P$ fertilizer value of MBM is of great interest because i) to high fertilization with $\mathrm{P}$ may cause $\mathrm{P}$ accumulation in soils and eutrophication of water bodies, and ii) uncontaminated $\mathrm{P}$ sources in the world are a limited resource.

Acknowledgements. This paper is an outcome of the project Meat and bone meal - documentation of fertilization and soil improvement effects, which was funded by Norsk landbrukssamvirke, Norsk Protein A/S and the programme ORIO - Organic Waste Products and Recycling of Resources (Grant no. 0124). 
Vol. 13 (2004): 268-275.

\section{References}

Bremner, J.M. 1960. Determination of nitrogen in the soil by the Kjeldahl method. Journal of Soil Science 55: 11-33.

Brewer, M.S. 1999. Current status of Bovine Spongiform Encephalopathy - a review. Journal of Muscle Foods 10: $97-117$

EFSA 2004. EFSA publishes Geographical BSE-Risk (GBR) assessment for Australia, Canada, Mexico, Norway, South Africa, Sweden and the United States of America. European Food Safety Authority, $20 \mathrm{Au}$ gust 2004. Available on the internet: http://www. efsa.eu.int/press_room/press_release $/ 575$ en.html

Eghball, B. 1996. Phosphorus and nitrogen based manure and compost applications. Manure Matters 2, 9. Available on the internet: http://manure.unl.edu/ v2n9 96.html

Egnér, H., Riehm, H. \& Domingo, W.R. 1960. Untersuchungen über die chemische Bodenanalyse als grundlage für der Beurteilung des Nährstoffzustandes der Böden. II. Chemische Extractions methoden zur Phosphor und Kaliumbestimmung. Statens Jordbruksforsök, särtrykk och småskrifter nr. 133, Uppsala.

EU commission 2000. Report on the assessment of the geographical BSE-risk (GPR) of Norway. EU-commission, Scientific Steering Committee. Available on the internet: http://europa.eu.int/comm/food/fs/sc/ssc/ out134 en.pdf

FAO 1998. World reference base for soil resources. World Soil Resources Reports 84. FAO, Rome. 88 p.

Fossum, K., Hopp, P. \& Høgåsen, H. 2001. Foreløpig risikovurdering for alternative behandlingsmåter for slakteriavfall. Rapport. Veterinærinstituttet. 12 p. (in Norwegian).

Fredriksson, H., Salomonsson, L., Andersson, R. \& Salomonsson, A.C. 1998. Effects of protein and starch characteristics on the baking properties of wheat cultivated by different strategies with organic fertilizers and urea. Acta Agriculturae Scandinavica, Section B-Soil and Plant Science 48: 49-57.

Fredriksson, H., Salomonsson, L. \& Salomonsson, A.C. 1997. Wheat cultivated with organic fertilizers and urea: Baking performance and dough properties. Acta Agriculturae Scandinavica, Section B-Soil and Plant Science 47: 35-42.

Hendriks, W.H., Butts, C.A., Thomas, D.V., James, K.A.C., Morel, P.C.A. \& Verstegen, M.W.A. 2002. Nutritional quality and variation of meat and bone meal. AsianAustralasian Journal of Animal Sciences 15: 15071516.

Henriksen, Aa. \& Selmer-Olsen, A.R. 1970. Automatic methods for determining nitrate and nitrite in water and soil extracts. Analyst 95: 514-518.

Kamphues, J. 2002. Feeding and feed legislation after the detection of the first indigenous BSE cases in Germany. Deutsche Tierarztliche Wochenschrift 109: 362-367.

Lazarovits, G. 2001. Management of soil-borne plant pathogens with organic soil amendments: a disease control strategy salvaged from the past. Canadian Journal of Plant Pathology-Revue Canadienne De Phytopathologie 23: 1-7.

Lazarovits, G., Conn, K.L. \& Potter, J. 1999. Reduction of potato scab, verticillium wilt, and nematodes by soymeal and meat and bone meal in two Ontario potato fields. Canadian Journal of Plant PathologyRevue Canadienne De Phytopathologie 21:345-353.

Lindén, B. 1997. Human urine as a nitrogen fertilizer applied during crop growth to winter wheat and oats in organic farming. Swedish University of Agricultural Sciences, Dept. of Agricultural Research, Skara. Series $B$ Crops and Soil, Report 1. $25 \mathrm{p}$.

Lundström, C. \& Lindén, B. 2001. Nitrogen effects of human urine, meat bone meal (Biofer) and chicken manure (Binadan) as fertilisers applied to winter wheat, spring wheat and spring barley in organic farming. Swedish University of Agricultural Sciences, Dept. of Agricultural Research Skara, Series B Crops and Soil, Report 8. 51 p.

Norwegian Ministry of Agriculture 2002. Forskrift om begrensninger for bruk av gjødsel, jordforbedringsmidler, dyrkingsmedier m.v. som inneholder kompostert animalsk avfall eller foredlede animalske protein er. FOR 2002-01-24 nr 63. Available on the internet: http://www.lovdata.no/for/sf/ld/xd-200201240063.html. (In Norwegian).

NS 4770. Water analysis - Determination of metals by atomic absorption spectrophotometry, atomization in flame - General principles and guidelines. Norges Standardiseringsforbund, 1994. Second edition.

NS-EN 12176. Characterization of sludge - Determination of $\mathrm{pH}$-value. Norges Standardiseringsforbund, 1998. First edition.

Salomonsson, L., Jonsson, A., Salomonsson, A.C. \& Nilsson, G. 1994. Effects of organic fertilizers and urea when applied to spring wheat. Acta Agriculturae Scandinavica, Section B-Soil and Plant Science 44: $170-178$.

Salomonsson, L., Salomonsson, A.C., Olofsson, S. \& Jonsson, A. 1995. Effects of organic fertilizers and urea when applied to winter wheat. Acta Agriculturae Scandinavica, Section B-Soil and Plant Science 45: $171-180$.

Selmer-Olsen, A.R. 1971. Determination of ammonium in soil extracts by an automated indophenol method. Analyst 16: 565-568. 